\title{
CANTOS DEL OFRECIMIENTO
}

\section{Juan PANERO \\ Sergio SANTIAGO ROMERO (Edición y estudio)}

\begin{abstract}
(Astorga: Asociación de Amigos Casa Panero / Centro de Estudios Astorganos “Marcelo Macías”, 2017, 152 págs.)
\end{abstract}

Cantos del ofrecimiento fue publicada por primera vez en 1936 en la colección "Héroe", dirigida por Manuel Altolaguirre. Juan Panero - hermano de Leopoldo Panero y, con él, inaugurador de un cosmos poético familiar fascinante - moría al año siguiente. Su temprana muerte, lo reducido de su producción, la notable obra del hermano y la turbulenta historia familiar oscurecieron la presencia de esta brillante figura y su obra, que pasó prácticamente inadvertida durante décadas para la historiografía de la literatura española. Si bien su producción continuó viviendo en la inmediata posguerra —en revistas como Escorial, Arriba o Espadaña-, autor y obra apenas fueron atendidos hasta la publicación de su Obra poética en 1987, recopilada y estudiada por Elisa Domínguez de Paz.

La presente edición supone un eslabón clave en el camino hacia su recuperación, en tanto que rescata y coteja el texto íntegro de la de 1936 y añade un exhaustivo y agudo estudio, así como un comentario y notas a los poemas - aparato crítico y análisis ecdótico completos-, y un repaso actualizado de toda la bibliografía sobre y de Juan Panero: ediciones, 
textos publicados en revistas y documentos de archivo - libretas, copias manuscritas, epistolarios y documentación perteneciente al archivo de su hermano Leopoldo-. A través del estudio, los comentarios y las notas, se descubren un poeta originalísimo y un estudioso con una visión asimismo novedosa: Sergio Santiago Romero supera una tradicional y simplificadora lectura amorosa y virgiliana del poemario, resaltando sus matices místicos, eróticos y nietzscheanos, demostrando con ello una lectura atenta, reflexiva y sensible.

El estudio recorre en profundidad figura y obra del autor: notas biográficas, análisis de su recuperación, influencias y legado. Un joven Juan Panero - en sus primeras incursiones poéticas, la formación de la Escuela de Astorga y la fundación de La Saeta; y en sus vivencias al comenzar la guerra en tanto que "católico y republicano" que luchó con el bando Nacional (59) - es revelado por Santiago Romero, quien localiza y esclarece profundas lagunas biográficas a través de fuentes primarias, a menudo localizadas en el archivo de Leopoldo.

Las secciones "La memoria de un olvido" (62-70), "Algunas influencias" (71-74) y "Puentes de agua entre el 36 y el 27" (75-81) revelan el lugar que correspondió a Juan Panero en su tiempo y el legado inmaterial que transmitió. Como recientemente descubría Javier Huerta Calvo - prologuista de esta edición, en Gerardo Diego y la Escuela de Astorga (2015) - , y recoge Santiago Romero, Cantos del ofrecimiento formaba parte de un proyecto poético, editorial y crítico de lanzamiento de las voces del 36 que nunca se materializó. Su impronta penetró en la obra de sus coetáneos, como Santiago Romero demuestra a través de dos ejemplos: el símbolo de la nieve, originario de Cantos del ofrecimiento y fundamental para la primera generación de posguerra — con La estancia vacía (1944) de Leopoldo Panero y La casa encendida (1949) de Luis Rosales como innegables herederas - ; y el motivo de la muerte, que es analizado en 
dos vertientes: la de la amada muerta y la de la muerte en tanto que "estado auténtico", "espacio privilegiado" para acceder a la verdad, de raíces nietzscheanas y latencia posterior en la obra de su sobrino Leopoldo María. A estos elementos habría que sumar una tercera característica que confirma la modernidad del poemario: la estructura circular del conjunto, y la tradicional y vanguardista de sus poemas, sonetos y composiciones en versículos whitmanianos de gran éxito en la poesía de posguerra.

Todavía más interesantes resultan los siguientes apartados: "La sombra de Novalis" (87-100), "La Luz de Neruda, entre la vanguardia y la tradición" (100-107) y, especialmente, "El vitalismo trágico de Juan Panero" (108-125). Atraviesa en ellos un haz de lecturas e influencias que van desde Virgilio, Novalis y Machado en su "misticismo amoroso", hasta el Neruda de Residencia en la tierra para su vanguardismo-surrealista, y Nietzsche para su concepción de vida trágica. La primera de estas influencias, si bien ha sido ya advertida por la crítica, es matizada por Santiago Romero, quien demuestra la proximidad del tono general del poemario no al generalmente señalado carácter amoroso — que apunta hacia concepciones tradicionales corteses-, sino a un "erotismo natural" y un sentido vitalista de ofrecimiento del yo a la contemplación y el canto. En cuanto a los ecos vanguardistas en la poesía de Juan Panero, discutidos por la crítica, son confirmados y afinados por Santiago Romero a través de una comparativa entre imágenes y concepciones heredadas por Neruda. El último apartado contiene la tesis más atrevida y novedosa, que su autor ya sugiriera en su artículo "La huella de Nietzsche en la obra de los Panero" (Filosofía hoy, 42: 18-19): el eco del filósofo, a quien Panero conocería a través de la palabra de Ortega, en la "línea jubilar y positiva" de su poesía, manifestada incluso frente al dolor. "Profunda agonía" ya vislumbrada por la crítica bajo la serenidad guilleniana, cuyas posturas arraigan en un cristianismo tamizado por las ideas de Nietzsche y Ortega; poética no 
virgiliana sino trágica, en canto al mundo no por su perfección sino por una aceptación en su dimensión completa y contradictoria, entroncando así con el "sentido trágico de un vitalismo desbordante" del alemán (114 y ss.). Poesía, en fin, que no es sólo contemplación y canto, sino también vivencia: "Vida y literatura se hacen uno en el esfuerzo estético y existencial de Juan Panero" (118).

La presente edición supone revisión crítica y aportación original sobre la vida del poeta, repaso por las fuentes para una aproximación biobibliográfica al autor y su obra, y pausado y profundo análisis del texto. A estos fines se suman otros, como la contribución a un mayor conocimiento de la recepción de Nietzsche en España, y a una profundización en los orígenes esenciales de una poética de posguerra. Bajo un estilo cuidado y exquisito, esta edición de los Cantos del ofrecimiento entronca con la voluntad crítica actual de recuperación de una España literaria del pasado siglo olvidada por cuestiones estéticas o canónicas, vicisitudes históricas $\mathrm{y}$ vitales.

Lucía Cotarelo Esteban

Universidad Complutense de Madrid 